\title{
THE EFFECT OF FARMING METHOD ON THE DYNAMICS OF COMMUNITIES FROM THE ALLIANCE Radiolion linoidis (RIAS GODAY 1961) PIETACH 1965 IN KAEUSZYN UPLAND AGROCENOSES
}

\author{
Teresa Skrajna \\ Department of Agricultural Ecology, University of Nature Science and Humanity \\ B. Prusa 14, 08-110 Siedlce, Poland \\ e-mail: tskrajna@op.pl
}

Received: 15.12 .2012

\section{Abstract}

The work presents the results of studies carried out from 1994 to 2010 on changes in phytocenoses with Radiolion linoidis species due to increased intensification of the farming process. The research material consisted of 136 phytosociological relevés taken from the same sites located in cereals, tuber crops/maize and stubble fields. The relevés were grouped based on three periods reflecting changes in farming system: period I (1994-1997) - traditional farming system; period II (2002-2004) - shift from traditional to intensive farming; period III (2008-2010) - intensive farming system. Communities with Radiolion linoidis continued to disappear over the whole study period due to farming intensification. The phytocenoses Spergulario-Illecebretum verticillati found in stubble fields and communities with Illecebrum verticillatum observed in cereals and tuber crops in period I were replaced with patches of Echinochloo-Setarietum in maize and stubble fields as well as the association Vicietum tetraspermae in cereals in period III. The values of Sørensen's index of community similarity and of the dynamics index emphasize how advanced the process of changes in and impoverishment of communities was.

Key words: field weeds, threatened species, field under cultivation, dynamics index (V), Sørensen's index of similarity

\section{INTRODUCTION}

Intensive development of agricultural production technology in Europe began in the first part of the $20^{\text {th }}$ century [1] and in Poland in the second part of the $20^{\text {th }}$ century. Modern agrotechnology and intensive application of chemicals in field production have led to the disappearance of many specialised species and whole communities [2-5]. Other factors that have promoted the impoverishment of flora in agrocenoses include abandoning marginal land, reduced diversity of cultivated fields, for example smaller percentages of fields under Secale cereale L. and Linum usitatissimum L., and ploughing under of stubble fields which are the main place where many short-lived ground species develop [6,7]. They also include communities with Radiolion linoidis included in the list of endangered segetal communities in Poland [8].

In the study area, traditional cultivation methods in the 1990s supported communities from the alliance Radiolion linoidis with a large share of Illecebrum verticillatum in agrocenoses [9-13].

The purpose of this work was to analyse transformations of communities from the alliance Radiolion linoidis due to changes in habitat conditions resulting from intensification of the farming process.

\section{MATERIALS AND METHODS}

Field observations were performed over the period 1994-2010 in the same sites located in cultivated fields of 23 localities of the Kałuszyn Upland [14] (Fig. 1). There was a total of 136 phytosociological relevés taken using the Braun-Blanquet approach [15] in fields under cereals, root crops/maize and in stubble fields. Next, the relevés were grouped according to the following three periods to reflect changes in farming methods:

- period I (1994-1997) - traditional farming system;

- period II (2002-2004) - transformation period shift form traditional to intensive farming;

- and period III (2008-2010) - intensive farming system. 


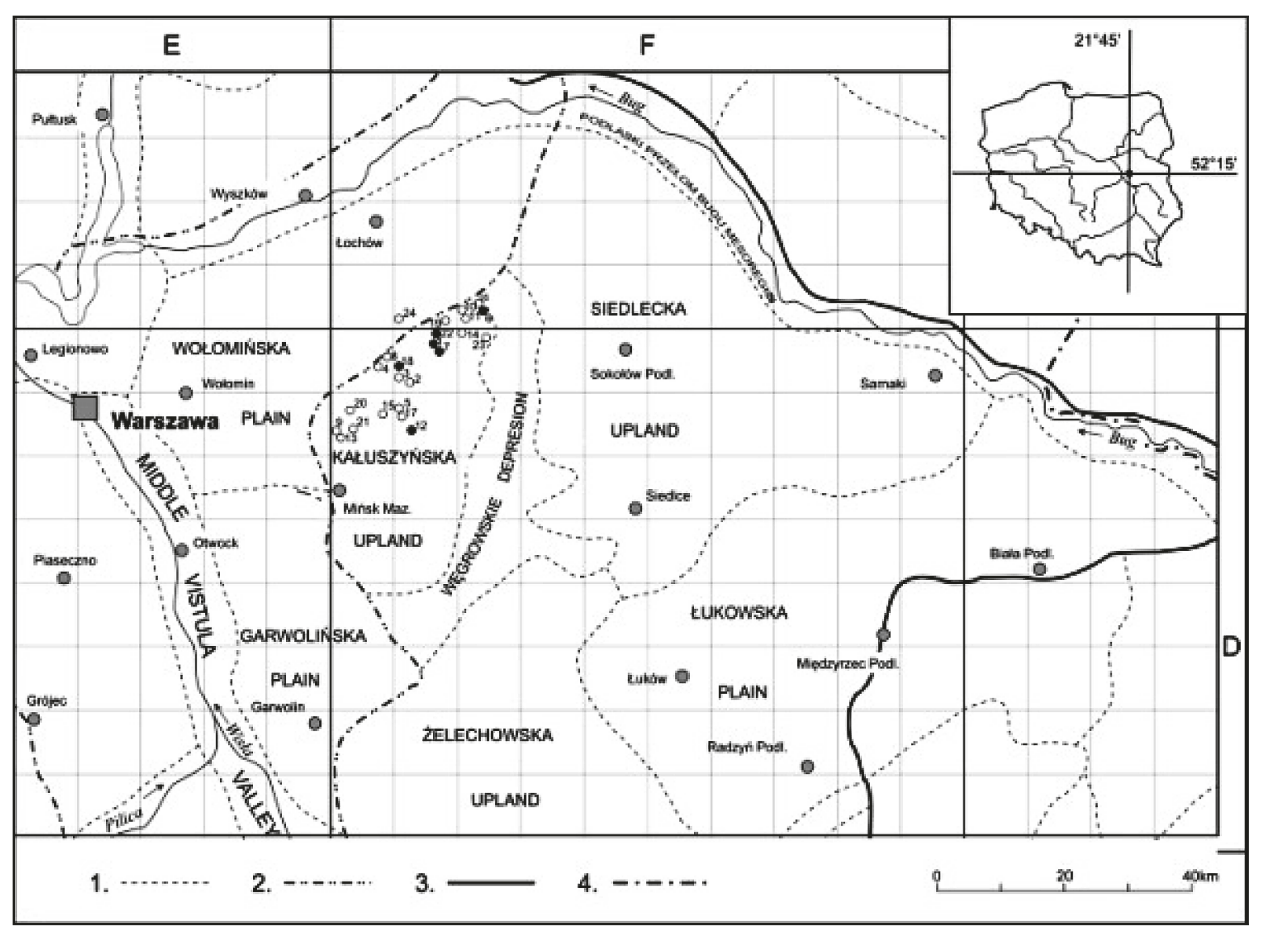

Fig. 1. The location of study area.

1- current locality Illecebrum verticillatum (2008-2010); 2 - locality Illecebrum verticillatum do 1994-2002; 3 - limits of the mesoregions; 4 - limits of the macroregions; 5 - limits of the provinces; 6 - borders of coumtry.

Data on the changes in farming intensification and percentages of area under individual crops were derived from surveys carried out among the owners of the fields where permanent study areas were located. Soil conditions were determined using agricultural soil maps at a scale of 1:5000. Relevés from the study periods were arranged into tables according to individual crops and stubble. Then, phytosociological classification was made [16] and used to analyse the structural changes in the communities.

Sørensen's index of similarity $\left(\mathrm{SW}_{\mathrm{s}}\right)$ was employed to reflect the extent of changes in communities in individual study periods. The index was calculated according to the following formula:

Moreover, the dynamics index $\mathrm{V}$ was used to analyse changes in the floristic composition of agrophytocenoses in the sites studied. The index reflects an increase or decrease in constancy of occurrence and is a measure of species dynamics [17]:

$$
V=S_{3} / S_{1} * 100 \%
$$

where:

$S_{1}-$ constancy of occurrence of a given species in period I (1994-1997);

$S_{3}-$ constancy of occurrence of a given species in period III (2008-2010).

The species which were characterised by an absolute increase or decrease in constancy of 4 percent points were considered to be species whose constancy changed significantly. Vascular plant terminology in the study followed M ir e k et al. [18].

\section{RESULTS}

Comparisons of the present state of the communities with their state 17 years ago revealed dynamic changes taking place in the structure of agrocenoses for all the crop groups and stubble fields. A number of community transformations associated with changes in the land use structure and farming intensification took place.

\section{Changes in stubble communities}

Changes in syntaxonomic affiliation of communities were observed in the study area in stubble fields. Two associations including lower units were recognised in period I: Spergulario-Illecebretum verticillati and Digitarietum ischaemi. They were floristically rich phytocenoses: there was a total of 113 species in stubble fields (Table 1). Number of species per relevé ranged between 26 and 53, on average 32 species. There was observed a mass occurrence of Illecebrum verticillatum in both associations. Moreover, a large cover of the following hygrophilous species was observed: species of the association Radiolion linoidis such as Hypericum humifusum, Radiola linoides and Centunculus minimus, of the classes Isoëto-Nanojuncetea - Juncus bufonius, Juncus capitatus, Gnaphalium uliginosum and Plantago intermedia as well as other moisture-loving species like the 
most numerous Veronica serpyllifolia, Polygonum hy- a mass occurrence of the following acidophilous weeds: dropiper and Sagina procumbens. There was observed Rumex acetostella and Spergula arvensis and others.

Table 1

Changes in stubble communities in years 1994-2010

\begin{tabular}{|c|c|c|c|c|c|c|}
\hline Farming system & \multicolumn{2}{|c|}{ traditional } & \multicolumn{2}{|c|}{ transformation period } & \multicolumn{2}{|c|}{ intensive } \\
\hline In period & \multicolumn{2}{|c|}{ 1994-1997 } & \multicolumn{2}{|c|}{$2002-2004$} & \multicolumn{2}{|c|}{$2008-2010$} \\
\hline Numbers of species with in the releve & \multicolumn{2}{|c|}{$26-5332$} & \multicolumn{2}{|c|}{$22-3727$} & \multicolumn{2}{|c|}{$19-2824$} \\
\hline Numbers of releves & \multicolumn{2}{|c|}{31} & \multicolumn{2}{|c|}{16} & \multicolumn{2}{|c|}{16} \\
\hline \multirow[t]{2}{*}{ No } & \multicolumn{2}{|c|}{1} & \multicolumn{2}{|c|}{2} & \multicolumn{2}{|c|}{3} \\
\hline & $\mathrm{S}$ & $\mathrm{D}$ & $\mathrm{S}$ & $\mathrm{D}$ & $\mathrm{S}$ & $\mathrm{D}$ \\
\hline \multicolumn{7}{|c|}{ I. Ch. Spergulario-Illecebretum verticillati } \\
\hline Illecebrum verticillatum & $\mathrm{V}$ & 1389 & IV & 250 & II & 31 \\
\hline Spergularia rubra & IV & 152 & III & 119 & II & 81 \\
\hline \multicolumn{7}{|l|}{ II. Ch. Radiolion linoidis } \\
\hline Hypericum humifusum & V & 839 & IV & 237 & II & 165 \\
\hline Radiola linoides & $\mathrm{V}$ & 397 & III & 75 & I & 6 \\
\hline Gypsophila muralis & II & 46 & II & 96 & I & 12 \\
\hline Centunculus minima & IV & 219 & III & 93 & $\mathrm{I}$ & 12 \\
\hline \multicolumn{7}{|l|}{ III. Ch. Isoëto-Nanojuncetea } \\
\hline Juncus bufonius & $\mathrm{V}$ & 516 & $\mathrm{~V}$ & 250 & IV & 162 \\
\hline Juncus capitatus & IV & 213 & IV & 112 & I & 12 \\
\hline Plantago intermedia & IV & 258 & III & 100 & II & 67 \\
\hline Gnaphalium uliginosum & $\mathrm{V}$ & 316 & III & 312 & III & 62 \\
\hline Gnaphalium luteo-album & II & 22 & $\mathrm{I}$ & 6 & $\mathrm{I}$ & 6 \\
\hline \multicolumn{7}{|l|}{ IV. D. var. hygrophilous species } \\
\hline Veronica serpyllifolia & $\mathrm{V}$ & 442 & IV & 187 & II & 5 \\
\hline Polygonum hydropiper & IV & 406 & III & 100 & III & 334 \\
\hline Sagina procumbens & IV & 179 & III & 69 & II & 18 \\
\hline Mentha arvensis & III & 555 & III & 93 & II & 87 \\
\hline Peplis portula & III & 147 & II & 50 & II & 319 \\
\hline Stachys palustris & II & 202 & II & 56 & III & 197 \\
\hline Bidens tripartita & II & 77 & II & 56 & IV & 372 \\
\hline Potentilla anserina & II & 32 & II & 31 & III & 68 \\
\hline Lysimachia nummularia & II & 64 & II & 31 & $\mathrm{I}$ & 19 \\
\hline \multicolumn{7}{|c|}{ IV. Ch. Aperion spicae-venti, Centauretalia cyani } \\
\hline Scleranthus annuus & IV & 87 & III & 50 & $\mathrm{I}$ & 19 \\
\hline Anthemis arvensis & III & 111 & IV & 112 & IV & 197 \\
\hline Centaurea cyanus & III & 51 & II & 69 & II & 25 \\
\hline Arnoseris minima & III & 61 & I & 6 & I & 43 \\
\hline Anthoxanthum aristatum & II & 58 & II & 25 & II & 75 \\
\hline Vicia hirsuta & II & 26 & II & 31 & II & 31 \\
\hline Apera spica-venti & II & 26 & II & 25 & I & 6 \\
\hline Vicia angustifolia & II & 25 & I & 19 & I & 12 \\
\hline Teesdalea nudicaulis & II & 32 & & & & \\
\hline \multicolumn{7}{|l|}{ V. Ch. Digitarietum ischaemi } \\
\hline Digitaria ischaemum & IV & 425 & $\mathrm{~V}$ & 628 & III & 281 \\
\hline \multicolumn{7}{|l|}{ VI. Ch. Echinochloo-Setarietum } \\
\hline Echinochloa crus-galli & $\mathrm{I}$ & 32 & IV & 1022 & V & 1246 \\
\hline Raphanus raphanistrum & III & 67 & II & 31 & II & 56 \\
\hline
\end{tabular}




\begin{tabular}{|c|c|c|c|c|c|c|}
\hline \multicolumn{7}{|l|}{ VII. Ch. Panico-Setarion } \\
\hline Spergula arvensis & $\mathrm{V}$ & 135 & IV & 87 & II & 87 \\
\hline Rumex acetosella & $\mathrm{V}$ & 585 & III & 106 & III & 81 \\
\hline Setaria pumila & II & 61 & IV & 578 & IV & 584 \\
\hline Setaria viridis & II & 58 & III & 284 & II & 100 \\
\hline \multicolumn{7}{|c|}{ VIII. Ch. Polygono-Chenopodietalia Polygono-Chenopodion } \\
\hline Chenopodium album & III & 252 & $\mathrm{~V}$ & 569 & IV & 459 \\
\hline Polygonum aviculare s. & III & 58 & IV & 62 & III & 68 \\
\hline Sonchus arvensis & II & 22 & I & 44 & I & 37 \\
\hline Galinsoga parviflora & & & II & 35 & III & 203 \\
\hline Veronica persica & & & II & 100 & II & 184 \\
\hline Capsella bursa-pastoris & I & 6 & $\mathrm{I}$ & 12 & II & 25 \\
\hline \multicolumn{7}{|l|}{ IX. Ch. Stellarietea mediae } \\
\hline Viola arvensis & IV & 61 & IV & 451 & IV & 284 \\
\hline Fallopia convolvulus & IV & 81 & IV & 112 & II & 56 \\
\hline Stellaria media & III & 80 & $\mathrm{~V}$ & 600 & IV & 265 \\
\hline Matricaria maritima subsp. inodora & I & 69 & II & 106 & IV & 353 \\
\hline Conyza canadensis & II & 106 & II & 37 & II & 62 \\
\hline Myosotis arvensis & $\mathrm{I}$ & 22 & $\mathrm{I}$ & 6 & II & 37 \\
\hline \multicolumn{7}{|l|}{ X. Accompanying species } \\
\hline Achillea millefolium & IV & 64 & III & 44 & I & 19 \\
\hline Elymus repens & III & 71 & III & 106 & III & 725 \\
\hline Equisetum arvense & III & 61 & III & 69 & & \\
\hline Veronica arvensis & II & 26 & II & 31 & III & 125 \\
\hline Polygonum lapatifolium & II & 45 & II & 25 & III & 68 \\
\hline Cerastium holosteoides & II & 26 & II & 31 & I & 6 \\
\hline Cirsium arvense & II & 39 & I & 37 & I & 44 \\
\hline Convolvulus arvensis & II & 26 & I & 19 & I & 12 \\
\hline Ranunculus repens & II & 35 & I & 9 & I & 6 \\
\hline Hypochoeris radicata & II & 8 & I & 6 & I & 12 \\
\hline Plantago lanceolata & II & 6 & I & 6 & I & 6 \\
\hline Erodium cicutarium & II & 29 & I & 6 & I & 6 \\
\hline Leontodon autumnalis & II & 48 & & & I & 6 \\
\hline Polygonum persicaria & I & 13 & II & 56 & III & 100 \\
\hline Rorippa sylvestris & I & 13 & & & III & 184 \\
\hline Trifolium repens & I & 13 & & & II & 25 \\
\hline Agrostis stolonifera & I & 6 & & & II & 128 \\
\hline
\end{tabular}

Sporadical species: II - Ranunculus sardous 1,2; Riccia sorocarpa 1; Anthoceros punctatus 1; IV - Arabidopsis thaliana 1,2,3; Odontites verna 1,2; Myosotis stricta 1,2; Polygonum tomentosum 1,3; Vicia tetrasperma 1; Vicia sativa 1; Spergula morisonii 1; Chamomilla recutita 1; Melandrium noctiflorum 2,3;VIII-Atriplex patula 1,2,3;Geranium pusillum 1,2,3; Oxalis fontana 1,2,3; Rumex crispus 1; Euphorbia helioscopia 2,3; Lamium purpureum 2,3; Chenopodium polyspermum2,3; Sonchus oleraceus 2; Sonchus asper 2; Veronica agrestis 2; IX-Galeopsis tetrahit 1,2,3; Thlaspi arvense 2,3; Lapsana communis 3; Sinapis arvensis 3; X-Stellaria graminea 1,2,3;Poa апnua 1,2,3; Plantago major1,2,3; Equisetum sylvaticum1,2,3; Trifolium arvense 1,2; Medicago lupulina 1,2; Galeopsis ladanum 1,2; Holcus lanatus 1,2; Cerastium semidecandrum 1,2; Arenaria serpyllifolia 1,3; Amaranthus retroflexus 1,3; Taraxacum officinale 1,3; Symphytum officinale 1,3; Potentilla norvegica 1,3; Lactuca serriola 1; Medicago sativa s. falcata 1; Lysimachia vulgaris 1; Artemisia vulgaris 1; Tanacetum vulgare 1; Chamomilla suaveolens 1; Cerastium arvense 1; Lathyrus pratensis 1; Polygonum amphibium 1;Artemisia campestris 1; Allium vineale 1; Dactylis glomerata 1; Knautia arvensis 1; Hieracium pilosella 1; Hypericum perforatum 1; Trifolium pratense 1; Galium aparine 2,3; Crepis capillaris 2; Daucus carota 3; Epilobium montanum3; Gnaphalium sylvaticum 3; Tussilago farfara 3;

Explanatory notes: numbers after species inform about numbers of columns in the table:

$\mathrm{S}$ - phytosociological constancy, D - cover factor; 
In period II, one more association was distinguished, i.e. Echinochloo-Setarietum, as well as the community Setaria pumilla-Setaria viridis. The cover of Illecebrum verticillatum, all the species from Radiolion linoidis and Isoëto-Nanojuncetea and acidophilous species was markedly reduced. On the contrary, a higher share of the following nitrophilous species was observed: Chenopodium album, Stellaria media and Matricaria maritima subsp. inodora. Additionally, new species established, e.g. Veronica persica and Galinsoga parviflora. The overall number of stubble species was lower: 85 . The average number of species per relevé was lower, too, and amounted to 27.

Period III saw an even faster rate of disappearance of species and whole syntaxa representing the class Isoëto-Nanojuncetea. What is more, phytocoenoses of the association Spergulario-Illecebretum verticillati were not found, whereas rare patches of Digitarietum ischaemii Illecebrum verticillatum were replaced by numerous plants of Polygonum hydropiper, Peplis portula and Bidens tripartita.

\section{Changes in weed communities of cereal crops}

At the beginning of the study, rye was the only winter cereal, with its cover ranging from 45 to $60 \%$. These agrocenoses included the association Arnoserido-Scleranthetum, either typical or the variant with Illecebrum verticillatum, as well as the community with Aperion spicae-venti, the variant with Illecebrum verticillatum. The vertical structure of the stand was not distinct and often consisted of just one stratum. Thinner rye stands at the stage of grain maturation favoured the development of ground weeds. Illecebrum verticillatum plants were common and were accompanied by numerous species of the association Radiolion linoidis and of the class Isoëto Nanojuncetea, in which the species with the highest constancy and cover included the following: Radiola linoides, Centunculus minimus, Hypericum humifusum, Juncus bufonius and Juncus capitatus. Arnoseris minima was also a numerous characteristic species in the lowest layer, whereas Apera spica-venti was the dominant species in the upper one (Table 2). Cereal communities were infested by 82 weedy species, on average 24 species per relevé.

In 2002-2004 the total area of land under winter cereals decreased and half of it was under Triticale. The average cover of this cereal was higher and reached $64 \%$. Higher stand density substantially reduced the development of ground weeds. Agrocenoses in this period included the community Aperion spicae-venti, the typical variant and the hygrophilous variant with Juncus bufonius and the dominating species Apera spica-venti. The withdrawing species included Arnoseris minima and other acidophilous species. What is more, there was a drastic drop in the constancy and cover of the following species from the order Radiolion linoidis: Illecebrum verticillatum, Radiola linoides, Centunculus minimus, and Hypericum humifusum. The greater cover of Matricaria maritima subsp. inodora, Vicia tetrasperma and Polygonum lapathifolium subsp. pallidum indicates the improved nutrient status of the habitats. Agrocenoses included 66 species. The number of species per-relevé was slightly lower and ranged from 15 to 29 , averaging 23 species. There was also a decrease in total weed cover.

Triticale was the only winter species cultivated in period III and its average cover reached $70 \%$. The agrophytocenoses underwent further transformations; the association Vicietum tetraspermae, the typical variant with Juncus bufonius and Rhinanthus serotinus, became the leading dominant. Great numbers of new species, Bromus secalinus and Vicia villosa, were found in some patches. In addition, the following nitrophilous newcomers increased their cover: Matricaria maritima subsp. inodora, Sonchus arvensis and Galium aparine. Hygrophilous species of the alliance $R a$ diolion linoidis became very rare, whereas moisture-lowing species characterised by higher nutrient requirements, like Bidens tripartita, increased their cover. The community was made up of 65 species, 22 species per relevé on average.

\section{Changes in weed communities of tuber crops/maize}

In period I, potatoes were grown for livestock under the traditional farming system. They were characterised by substantial secondary weed infestation. These phytocenoses included two associations; Digitarietum ischaemi was frequently found in the typical variant and the variant with Illecebrum verticillatum, whereas the variant with Echinochloo-Setarietum sperguletosum was infrequent (Table 3). Hygrophilous species from the class Isoëto-Nanojuncetea - Juncus bufonius and Illecebrum verticillatum, present in all patches at high cover, made them easily recognisable. These phytocenoses consisted, respectively, of a total of 61 and 19 species per patch, on average.

During the period of farming process transition, $60 \%$ of cropped land was under maize. Patches of Digitarietum ischemii were seldom, whereas patches of Echinochloo-Setarietum became the dominant association which was much more diversified internally compared to period I. Hygrophilous species representing the syntaxa analysed clearly withdrew from the phytocenoses. Similarly, there was a clear decrease in the number of acidophilous species, particularly Spergula arvensis, Anthemis arvensis and Rumex acetosel$l a$. Moreover, there was observed a marked increase in the share of panicoid weeds but the overall weed cover 
in maize decreased. Also, the number of species making up the phytocenoses and the average number of species per relevé diminished (58 and 15, respectively). The above-mentioned changes progressed during the period of intensive farming, when only maize was cultivated. The dominance of Echinochloa crus-galli increased by further $30 \%$ compared with the previous period. The number and cover of nitrophilous species increased, the greatest changes being observed for Thlaspi arvense. The overall number of species slightly decreased to a level of 50, but the average number of species per patch remained the same.

Tabela 2

Changes in weed communities of cereal crops in years 1994-2010

\begin{tabular}{|c|c|c|c|c|c|c|}
\hline Farming system & \multicolumn{2}{|c|}{ traditional } & \multicolumn{2}{|c|}{ transformation period } & \multicolumn{2}{|c|}{ intensive } \\
\hline In period & \multicolumn{2}{|c|}{ 1994-1997 } & \multicolumn{2}{|c|}{$2002-2004$} & \multicolumn{2}{|c|}{$2008-2010$} \\
\hline \multirow{2}{*}{ Numbers of species with in the releve } & \multicolumn{2}{|c|}{$17-32$} & \multicolumn{2}{|c|}{$15-29$} & \multicolumn{2}{|c|}{$17-27$} \\
\hline & \multicolumn{2}{|c|}{24} & \multicolumn{2}{|c|}{23} & \multicolumn{2}{|c|}{22} \\
\hline Numbers of releves & \multicolumn{2}{|c|}{23} & \multicolumn{2}{|c|}{10} & \multicolumn{2}{|c|}{10} \\
\hline Cultivated plant: & \multicolumn{2}{|c|}{ Secale cereale } & \multicolumn{2}{|c|}{ Secale cereale/Triticale } & \multicolumn{2}{|c|}{ Triticale } \\
\hline \multirow[t]{2}{*}{ no } & \multicolumn{2}{|c|}{1} & \multicolumn{2}{|c|}{2} & \multicolumn{2}{|c|}{3} \\
\hline & $\mathrm{S}$ & $\mathrm{D}$ & $\mathrm{S}$ & $\mathrm{D}$ & $\mathrm{S}$ & $\mathrm{D}$ \\
\hline \multicolumn{7}{|l|}{ I. Ch. Isoëto-Nanojuncetea } \\
\hline Juncus bufonius & $\mathrm{V}$ & 502 & $\mathrm{~V}$ & 465 & III & 275 \\
\hline Juncus capitatus & IV & 215 & III & 40 & & \\
\hline Plantago intermedia & III & 61 & III & 100 & II & 30 \\
\hline Gnaphalium uliginosum & III & 123 & III & 180 & II & 70 \\
\hline \multicolumn{7}{|l|}{ II. Ch. Radiolion Linoidis } \\
\hline Hypericum humifusum & IV & 306 & III & 90 & II & 40 \\
\hline Radiola linoides & $\mathrm{V}$ & 572 & III & 50 & $\mathrm{I}$ & 10 \\
\hline Gypsophila muralis & $\mathrm{I}$ & 17 & II & 30 & I & 10 \\
\hline Centunculus minimus & $\mathrm{V}$ & 274 & II & 80 & I & 20 \\
\hline Myosurus minimus & II & 69 & III & 130 & II & 70 \\
\hline \multicolumn{7}{|c|}{ III. Ch. Spergulario-Illecebretum verticillati } \\
\hline Illecebrum verticillatum & $\mathrm{V}$ & 865 & IV & 150 & II & 20 \\
\hline Spergularia rubra & IV & 83 & II & 30 & II & 30 \\
\hline \multicolumn{7}{|l|}{ IV. D. var. hygrophilous species } \\
\hline Polygonum hydropiper & IV & 174 & III & 140 & IV & 140 \\
\hline Sagina procumbens & IV & 189 & II & 40 & II & 30 \\
\hline Peplis portula & III & 113 & III & 50 & II & 40 \\
\hline Veronica serpyllifolia & III & 61 & III & 50 & I & 10 \\
\hline Bidens tripartita & III & 56 & III & 50 & IV & 60 \\
\hline Mentha arvensis & II & 74 & II & 80 & II & 30 \\
\hline Stachys palustris & II & 35 & II & 40 & II & 80 \\
\hline Potentilla anserina & II & 22 & I & 20 & I & 20 \\
\hline Lysimachia nummularia & $\mathrm{I}$ & 13 & III & 20 & & \\
\hline \multicolumn{7}{|l|}{ V. Ch. Arnoserido-Scleranthetum } \\
\hline Arnoseris minimus & III & 350 & I & 10 & & \\
\hline Anthoxanthum aristatum & II & 133 & II & 30 & III & 130 \\
\hline Scleranthus annuus & II & 22 & $\mathrm{I}$ & 90 & $\mathrm{I}$ & 10 \\
\hline
\end{tabular}




\begin{tabular}{|c|c|c|c|c|c|c|}
\hline \multicolumn{7}{|l|}{ VI. Ch. Vicietum tetraspermae } \\
\hline Vicia tetrasperma & I & 6 & II & 235 & IV & 520 \\
\hline Bromus secalinus & & & & & III & 345 \\
\hline Polygonum tomentosum & I & 13 & II & 30 & II & 40 \\
\hline \multicolumn{7}{|l|}{ VII. Ch.D. Aperion spicae-venti } \\
\hline \multicolumn{7}{|l|}{ Centauretalia cyani } \\
\hline Apera spica-venti & $\mathrm{V}$ & 750 & V & 785 & $\mathrm{~V}$ & 505 \\
\hline Anthemis arvensis & IV & 233 & IV & 355 & IV & 200 \\
\hline Spergula arvensis & IV & 91 & IV & 110 & II & 80 \\
\hline Centaurea cyanus & III & 74 & III & 90 & III & 60 \\
\hline Vicia hirsuta & I & 128 & II & 370 & III & 360 \\
\hline Arabidopsis thaliana & I & 4 & I & 10 & II & 70 \\
\hline Vicia angustifolia & I & 9 & I & 10 & II & 30 \\
\hline Vicia villosa & & & & & III & 500 \\
\hline \multicolumn{7}{|l|}{ VII. Ch. Stellarietea mediae } \\
\hline Viola arvensis & IV & 96 & $\mathrm{~V}$ & 170 & $\mathrm{~V}$ & 210 \\
\hline Fallopia convolvulus & III & 52 & IV & 70 & IV & 110 \\
\hline Stellaria media & II & 22 & I & 20 & II & 30 \\
\hline Polygonum aviculare s. & II & 22 & II & 30 & I & 20 \\
\hline Chenopodium album & II & 22 & I & 10 & $\mathrm{I}$ & 10 \\
\hline Myosotis arvensis & II & 26 & I & 20 & II & 30 \\
\hline Matricaria maritima subsp. inodora & I & 9 & III & 130 & III & 220 \\
\hline Sonchus arvensis & I & 17 & & & III & 130 \\
\hline Oxalis fontana & I & 4 & I & 10 & II & 30 \\
\hline Echinochloa crus-galli & & & $\mathrm{I}$ & 20 & II & 30 \\
\hline \multicolumn{7}{|l|}{ VIII. Accompanying species } \\
\hline Rumex acetosella & IV & 243 & IV & 110 & II & 40 \\
\hline Equisetum sylvaticum & IV & 78 & III & 100 & II & 30 \\
\hline Veronica arvensis & II & 26 & II & 40 & III & 50 \\
\hline Cirsium arvense & II & 22 & II & 40 & II & 120 \\
\hline Elymus repens & II & 30 & & & I & 20 \\
\hline Equisetum arvense & II & 26 & I & 10 & I & 10 \\
\hline Rhinanthus serotinus & I & 52 & II & 120 & II & 235 \\
\hline Daucus carota & I & 13 & II & 20 & II & 30 \\
\hline Poa апnиа & I & 17 & II & 30 & II & 30 \\
\hline Arenaria serpyllifolia & & & I & 60 & II & 30 \\
\hline Galium aparine & & & & & III & 130 \\
\hline
\end{tabular}

Sporadical species: II - Riccia sorocarpa 1; Anthoceros punctatus 1; V-Teesdalea nudicaulis 1; VII - Capsella bursa-pastoris 1,2,3; Galeopsis tetrahit 1,2,3; Geranium pusillum 1,2; Digitaria ischaemum 1,2; Raphanus raphanistrum 1; Setaria pumila 1; Sonchus oleraceus 2,3; Conyza canadensis 3; VIII - Polygonum lapathfolium 1,2,3; Ranunculus repens 1,2,3; Achillea millefolium 1,2,3; Melandrium album 1,2,3; Cerastium arvense 1,2; Rumex obtusifolius 1,2; Trifolium repens 1,2; Rorippa sylvestris 1,2; Erodium cicutarium 1,2; Agrostis stolonifera 1,3; Convolvulus arvensis 1,3; Knautia arvensis 1,3; Lactuca serriola 1,3; Allium vineale 1; Cerastium holosteoides 1; Epilobium montanum 1; Galeopsis ladanum 1; Leontodon autumnalis 1; Lysimachia vulgaris 1; Medicago sativa falcata 1; Plantago lanceolata 1; Polygonum amphibium 1; Stellaria graminea 1; Cerastium semidecandrum 2; Symphytum officinale 3;

Explanatory notes: numbers after species inform about numbers of columns in the table:

$\mathrm{S}$ - phytosociological constancy, D - cover factor; 
Table 3

Changes in weed communities of tuber crops/maize in years 1994-2010

\begin{tabular}{|c|c|c|c|c|c|c|}
\hline Farming system & \multicolumn{2}{|c|}{ traditional } & \multicolumn{2}{|c|}{ transformation period } & \multicolumn{2}{|c|}{ intensive } \\
\hline In period & \multicolumn{2}{|c|}{ 1994-1997 } & \multicolumn{2}{|c|}{$2002-2004$} & \multicolumn{2}{|c|}{$2008-2010$} \\
\hline \multirow{2}{*}{ Numbers of species with in the releve } & \multicolumn{2}{|c|}{$17-24$} & \multicolumn{2}{|c|}{$13-18$} & \multicolumn{2}{|c|}{$14-18$} \\
\hline & \multicolumn{2}{|c|}{19} & \multicolumn{2}{|c|}{15} & \multicolumn{2}{|c|}{15} \\
\hline Numbers of releves & \multicolumn{2}{|c|}{10} & \multicolumn{2}{|c|}{10} & \multicolumn{2}{|c|}{10} \\
\hline \multirow[t]{2}{*}{ No. } & \multicolumn{2}{|c|}{1} & \multicolumn{2}{|c|}{2} & \multicolumn{2}{|c|}{3} \\
\hline & S & $\mathrm{D}$ & S & $\mathrm{D}$ & $\mathrm{S}$ & $\mathrm{D}$ \\
\hline \multicolumn{7}{|l|}{ I. Ch. Isoëto-Nanojuncetea } \\
\hline Juncus bufonius & $\mathrm{V}$ & 990 & III & 140 & II & 40 \\
\hline Gnaphalium uliginosum & III & 140 & II & 70 & & \\
\hline Juncus capitatus & II & 40 & & & & \\
\hline Plantago intermedia & & & I & 20 & $\mathrm{I}$ & 10 \\
\hline \multicolumn{7}{|l|}{ II. Ch. Radiolion linoidis } \\
\hline Hypericum humifusum & I & 10 & I & 20 & & \\
\hline Radiola linoides & II & 30 & & & & \\
\hline Ranunculus sardous & & & I & 10 & & \\
\hline
\end{tabular}

\section{Ch. Spergulario-Illecebretum verticillati}

Illecebrum verticillatum

Spergularia rubra

$\begin{array}{cc}\text { V } & 630 \\ \text { II } & 40\end{array}$

II $\quad 0$

\section{D. var. hygrophilous species}

Bidens tripartita

Polygonum hydropiper

$\begin{array}{ll}\text { III } & 425 \\ \text { III } & 220\end{array}$

II

30

II

30

Mentha arvensis

Peplis portula

Veronica serpyllifolia

Potentilla anserina

Equisetum sylvaticum

Sagina procumbens

V. Ch. Digitarietum ischaemi

Digitaria ischaemum

\section{Ch. Echinochloo-Setarietum}

Echinochloa crus-galli

Raphanus raphanistrum

II 245

II 245

$\begin{array}{cc}\text { I } & 2 \\ \text { II } & 3 \\ & \\ \text { I } & 3 \\ \text { II } & 3 \\ \text { II } & 4\end{array}$

$\begin{array}{ccc} & \text { II } & 110 \\ 20 & \text { II } & 80 \\ 30 & \text { II } & 30 \\ & \text { II } & 160\end{array}$

II $\quad 30$

30

30 I 10

I 20

I 20

40

II

30

I 20

II

\section{Ch. Panico-Setarion}

Setaria pumila

Setaria viridis

Spergula arvensis

IV $\quad 422$

V

\begin{tabular}{l|l}
510 & V
\end{tabular}

Rumex acetosella

III $\quad 850$

50

V

\begin{tabular}{c}
1570 \\
20 \\
\hline
\end{tabular}

\begin{tabular}{cc} 
V & 2175 \\
I & 20 \\
\hline
\end{tabular}

VIII. Ch.D Polygono-Chenopodion

\section{Polygono-Chenopodietalia}

Chenopodium album

Galinsoga parviflora

III $\quad 30$

V

405

$\begin{array}{cc}\text { V } & 530 \\ \text { III } & 170 \\ \text { I } & 10 \\ \text { II } & 40\end{array}$

Capsella bursa-pastoris

\begin{tabular}{cccccc} 
IV & 315 & III & 80 & III & 130 \\
I & 10 & I & 60 & II & 80 \\
I & 10 & II & 40 & II & 80 \\
\hline
\end{tabular}




\begin{tabular}{lcccccc}
\hline IX. Ch. Stellarietea mediae & & & & & & \\
Viola arvensis & V & 120 & II & 30 & II & 30 \\
Anthemis arvensis & IV & 200 & II & 70 & II & 30 \\
Fallopia convolvulus & II & 80 & II & 30 & II & 30 \\
Centaurea cyanus & II & 50 & I & 20 & I & 20 \\
Conyza canadensis & II & 30 & & & & \\
Thlaspi arvense & I & 10 & II & 40 & III & 295 \\
Stellaria media & I & 60 & II & 30 & II & 40 \\
Matricaria maritima subsp. inodora & & & & & II & 40 \\
\hline X. Accompanying species & & & & & & \\
Elymus repens & V & 335 & IV & 150 & III & 140 \\
Achillea millefolium & II & 30 & I & 20 & I & 10 \\
Veronica arvensis & II & 70 & I & 20 & II & 30 \\
Cirsium arvense & II & 30 & I & 10 & I & 60 \\
Erodium cicutarium & II & 40 & I & 10 & I & 10 \\
Galeopsis ladanum & II & 40 & I & 10 & & \\
Polygonum persicaria & II & 30 & & & & \\
Amaranthus retroflexus & I & 50 & I & 60 & II & 30 \\
Polygonum lapathfolium & I & 20 & I & 20 & II & 120 \\
Galium aparine & I & 10 & II & 20 & II & 40 \\
Agrostis stolonifera & & & I & 20 & II & 30 \\
\hline Spon
\end{tabular}

Sporadical species: IV - Stachys palustris 1,2,3; Lysimachia nummularia 2; VIII - Euphorbia helioscopia 1,3; Polygonum aviculare s. 1; Chenopodium polyspermum 1; Sonchus oleraceus 2,3; Sonchus arvensis 2; IX - Anthoxanthum aristatum 1,2; Arnoseris minima 1; Scleranthus annuus 1; Vicia hirsuta 1; Vicia angustifolia 1; Vicia villosa 1; Vicia tetrasperma 3 ; Galeopsis tetrahit 1; Myosotis arvensis 2,3; Lapsana communis 2,3; X-Taraxacum officinale 1,2,3; Convolvulus arvensis 1,2,3; Equisetum arvense 1,2,3; Lactuca serriola 1,2,3; Erysimum cheiranthoides 1; Arenaria serpyllifolia 1; Equisetum sylvaticum 1; Stellaria graminea 1; Stellaria graminea 2; Ranunculus repens 2; Rhinanthus serotinus 2; Leontodon autumnalis 2; Knautia arvensis2; Cerastium holosteoides 2; Medicago falcata 2; Plantago lanceolata 2,3; Rorippa sylvestris 3; Poa annua 3;

Explanatory notes: numbers after species inform about numbers of columns in the table:

$\mathrm{S}$ - phytosociological constancy, D - cover factor;

\section{Index of community dynamics and similarity}

The comparison of the conditions in period I and II in the agrophytocenoses studied revealed changes leading to the impoverishment and simplification of communities. In the crop groups analysed, the number of disappearing and withdrawing species was not compensated by new taxa (Table 4).

92 species in stubble fields, 71 in cereals and 50 in tuber crops/maize displayed dynamic tendencies. The withdrawing species included stenotopic taxa, that is, hygrophilous and acidophilous species which were withdrawing due to changes in habitat conditions (Table 5). The group of spreading species was less numerous. These weeds have a wide ecological amplitude; moreover, they are usually common species/ taxa with a high nutrient requirement (Table 6).

The comparison of the communities for the period analysed by means of Sørensen's index $\left(\mathrm{SW}_{\mathrm{s}}\right)$ confirmed marked similarities between period I and II communities for all the crop groups analysed (Table 7). The changes in agrocenoses over these periods were slow. Much greater differences were found when periods II and III were compared. The value of the index diminished clearly, which was accompanied by an increase in field production intensification and changes in agrophytocenoses. The lowest value of the index was obtained when period I was compared with period III. The similarity was as low as $\mathrm{SW}_{\mathrm{s}}=0.29$ for tuber crops/maize. 
Table 4

Number of species responding to changes in farming methods

\begin{tabular}{lccc}
\hline \multicolumn{1}{c}{ Site } & Stubble & Cereals & Tuber crops / Zea mays \\
\hline Number of species found in period I only & 35 & 19 & 22 \\
Number of species found in period II only & 10 & 5 & 10 \\
Number of withdrawing species & 55 & 38 & 35 \\
Number of species with increasing cover & 27 & 33 & 15 \\
\hline
\end{tabular}

Table 5

Dynamic index of the weed secies decreasing the coverage in years 1994-1997 - 2008-2010

\begin{tabular}{|c|c|c|c|}
\hline Cultivated plant: & stubble field & cereals & root crops/ Zea mays \\
\hline Dynamic index & $\mathrm{V}$ & $\mathrm{V}$ & $\mathrm{V}$ \\
\hline Radiola linoides & 16 & 11 & 0 \\
\hline Juncus capitatus & 26 & 0 & 0 \\
\hline Centunculus minimus & 28 & 22 & \\
\hline Illecebrum verticillatum & 31 & 30 & 0 \\
\hline Gnaphalium luteoalbum & 32 & & \\
\hline Potentilla norvegica & 28 & & \\
\hline Gypsophila muralis & 35 & 58 & \\
\hline Hypericum humifusum & 45 & 51 & 0 \\
\hline Plantago intermedia & 61 & 63 & \\
\hline Sagina procumbens & 41 & 46 & 0 \\
\hline Gnaphalium uliginosum & 57 & 58 & 50 \\
\hline Veronica serpyllifolia & 39 & 23 & 0 \\
\hline Scleranthus anпuиs & 31 & 46 & 0 \\
\hline Digitaria ischaemum & 65 & 0 & \\
\hline Arnoseris minima & 39 & 0 & 0 \\
\hline Spergularia rubra & 51 & 46 & 75 \\
\hline Juncus bufonius & 65 & 73 & 44 \\
\hline Equisetum arvense & 39 & 38 & 50 \\
\hline Polygonum hydropiper & 87 & 86 & 67 \\
\hline Peplis portula & 83 & 92 & 100 \\
\hline Mentha arvensis & 68 & 77 & 100 \\
\hline Rumex acetosella & 65 & 66 & 57 \\
\hline Polygonum aviculare & 75 & 92 & 0 \\
\hline Raphanus raphanistrum & 75 & 0 & 40 \\
\hline Convolvulus arvensis & 48 & 77 & 50 \\
\hline Spergula arvensis & 47 & 54 & 17 \\
\hline Erodium cicutarium & 22 & 0 & 25 \\
\hline Fallopia convolvulus & 46 & & 75 \\
\hline Cirsium arvense & 73 & & 67 \\
\hline Oxalis fontana & 39 & & \\
\hline Galeopsis tetrahit & 32 & & 0 \\
\hline Myosotis arvensis & 55 & & \\
\hline Sonchus arvensis & 55 & & \\
\hline Centaurea cyanus & 48 & & 40 \\
\hline Plantago major & 48 & & \\
\hline Stellaria graminea & 48 & 0 & \\
\hline Vicia angustifolia & 48 & & 0 \\
\hline Lysimachia nummularia & 48 & 0 & \\
\hline Apera spica-venti & 24 & & \\
\hline Plantago lanceolata & 24 & 0 & \\
\hline Cerastium holosteoides & 22 & 0 & \\
\hline
\end{tabular}




\begin{tabular}{|c|c|c|c|}
\hline Poa апnиа & 65 & & \\
\hline Leontodon autumnalis & 22 & 0 & \\
\hline Ranunculus repens & 18 & & \\
\hline Achillea millefolium & 29 & & 33 \\
\hline Chenopodium album & & 46 & 71 \\
\hline Elymus repens & & 66 & 67 \\
\hline Potentilla anserina & & 92 & 50 \\
\hline Anthemis arvensis & & & 38 \\
\hline Viola arvensis & & & 38 \\
\hline Equisetum sylvaticum & & 49 & \\
\hline Myosurus minimus & & 86 & \\
\hline
\end{tabular}

Table 6

Dynamic index of the weed species increasing the coverage in years 1994-1997-2008-2010

\begin{tabular}{|c|c|c|c|}
\hline Cultivated plant: & stubble field & cereals & root crops/ Zea mays \\
\hline Dynamic index & $\mathrm{V}$ & $\mathrm{V}$ & $\mathrm{V}$ \\
\hline Amaranthus retroflexus & 581 & & 300 \\
\hline Echinochloa crus-galli & 517 & & 250 \\
\hline Capsella bursa-pastoris & 388 & 153 & 400 \\
\hline Veronica arvensis & 218 & 192 & 100 \\
\hline Polygonum lapathifolium subsp. lapathifolium & 151 & 58 & 200 \\
\hline Stellaria media & 149 & 138 & 200 \\
\hline Stachys palustris & 113 & 115 & 200 \\
\hline Matricaria maritima subsp. inodora & 504 & 690 & \\
\hline Arabidopsis thaliana & 129 & 690 & \\
\hline Arenaria serpyllifolia & 129 & 345 & \\
\hline Agrostis stolonifera & 388 & 115 & \\
\hline Polygonum lapathifolium subsp. pallidum & 291 & 307 & \\
\hline Bidens tripartita & 178 & 106 & \\
\hline Rorippa sylvestris & 161 & 115 & \\
\hline Vicia hirsuta & 121 & 230 & \\
\hline Galinsoga parviflora & 221 & & 300 \\
\hline Trifolium repens & 194 & & 200 \\
\hline Setaria pumila & 194 & & 300 \\
\hline Polygonum persicaria & 388 & & \\
\hline Symphytum officinale & 388 & & \\
\hline Geranium pusillum & 194 & & \\
\hline Chenopodium album & 145 & & \\
\hline Elymus repens & 138 & & \\
\hline Potentilla anserina & 136 & & \\
\hline Vicia tetrasperma & & 805 & \\
\hline Lactuca serriola & & 460 & \\
\hline Oxalis fontana & & 690 & \\
\hline Vicia angustifolia & & 345 & \\
\hline Sonchus arvensis & & 288 & \\
\hline Myosotis stricta & & 230 & \\
\hline Daucus carota & & 230 & \\
\hline Rhinanthus serotinus & & 173 & \\
\hline Cirsium arvense & & 153 & \\
\hline Fallopia convolvulus & & 134 & \\
\hline Veronica persica & & & 500 \\
\hline Galium aparine & & & 400 \\
\hline Euphorbia helioscopia & & & 200 \\
\hline Setaria viridis & & & 167 \\
\hline Equisetum sylvaticum & & & 150 \\
\hline
\end{tabular}


Table 7

Values of Sørensen's index for communities in individual study periods

\begin{tabular}{lccc}
\hline \multicolumn{1}{c}{ Periods compared } & I - II & II - III & I - III \\
\hline Stubble field & 0.456 & 0.405 & 0.355 \\
Secale cereale & 0.484 & 0.416 & 0.373 \\
Tuber crops / Zea mays & 0.336 & 0.318 & 0.291 \\
\hline
\end{tabular}

\section{DISCUSSION}

The changes due to farming intensification taking place over 17 years in the communities with Radiolion linoidis indicated an improved nutrient status of these habitats. The community composition and structure changed; all the syntaxa with species representing the aforementioned association disappeared in stubble fields, cereals and tuber crops. They were replaced by associations widespread in Poland and characterised by wide amplitude of habitats where they grow. The association Echinochloo-Setarietum was observed in stubble fields and maize, whereas Vicietum tetraspermae and species-impoverished communities representing the association Aperion spicae-venti were found in cereals. The scale of these transformations is also reflected in the low value of Sørensen's coefficient. The analysis of the changes in species composition of the communities in period I and III demonstrated that the species disappeared much faster than new ones appeared (Table 4, 5). Many works, both Polish and foreign, have examined the issue of impoverishment and disappearance of specialised communities [2,5,19-24].

Species that spread and reached the highest values of the dynamics index included eurytopic and nitrophilous species, such as: Echinochloa crus-galli, Chenopodium album, Galinsoga parviflora, Stellaria media, Matricaria maritima subsp. inodora and Elymus repens, which are believed to be common expansive weeds in Poland $[25,26]$. The establishment of these species is possible, because maize has become a dominant crop plant and now the area under maize is around $60 \%$ of cropped land. Communities establishing in maize consist of the smallest number of species (an average of 16 species per patch), compared with cereals or tuber crops. According to G o ł ę b i o w s k a and $\mathrm{Kaus}$ [27], the number of weedy species in maize depends on weed control methods and ranges from 11 to 16 species per relevé [28], whereas monoculture is associated with the following dominant species: Chenopodium album, Echinochloa crus-galli, Elymus repens and others [29]. The application of herbicides, e.g. triazine products, substantially reduces the development of weeds [28] whereas monoculture is associated with the development of weed dominance, for example Chenopodium album, Echinochloa crusgalli, Elymus repens, and others. Compensation of weeds which quickly develop resistance to herbicides has already been noticed in the agrocenoses studied, as exemplified by a mass occurrence of Echinochloa crus-galli

\section{CONCLUSIONS}

1. Communities from the Radiolion linoidis alliance were greatly reduced due to changes in farming methods.

2. Acidophilous phytocenoses Spergulario-Illecebretum verticillati disappeared in stubble fields, while phytocenoses with Illecebrum verticillatum in cereals and tuber crops.

3. Various forms of the common association Echinochloo-Setarietum established in maize and stubble fields, whereas patches of Vicietum tetraspermae in cereals.

4. The greatest differences were found for the communities between study period I and III, as reflected by a low value of Sørensen's index $\left(\mathrm{SW}_{\mathrm{s}}=0.29\right)$.

5. The impoverishment of communities took place; the number of disappearing and withdrawing species was higher than the number of new taxa.

\section{Acknowledgements}

Research supported by the Ministry of Science and Higher Education of Poland as part of the statutory of the Department of Agricultural Ecology, Siedlce University of Natural Sciences and Humanities.

\section{REFERENCES}

1. Ellis RH, Nelson IL, Hopkins GW, Hamlett BJ, Memmott J. Pollinator webs, plant communities and the conservation of rare plants: arable weeds as a case study: pollinator webs and rare plant conservation. J Appl Ecol. 2006; 43(2): 246-257. http://dx.doi.org/ 10.1111/j.1365-2664.2006.01130.x

2. Kornas J. The extinction of the association Sperguleto-Lolietum remoti in flax cultures in the Gorce (Polish Western Carpathian Mountains). Bull Acad Pol Sci. 1961; 2(9): 37-40.

3. Kulp HG, Cordes H. Veränderung der soziologischen Bindung in Ackerwildkraut-Gesellschaften auf Sandböden. Tuexenia. 1986; (6): 25-36. 
4. Popiela A. The distribution of character species of the Isoëto-Nanojuncetea-class in Poland: Centunculus minimus, Radiola linoides and Ilecebrum verticillatum. Fragm Flor Geobot. 1998; 43(2): 223-230.

5. Los os ová Z. Estimating past distribution of vanishing weed vegetation in South Moravia. Preslia. 2003; 75(1): 71-79.

6. Hoste I, van Landuyt W, Verloove F. Landschap en flora in beweging, 19de en 20ste eeuw. In: van Landuyt W, Hoste I, Vanhecke L, van den Bremt P, Vercruysse W, de Beer D, editors. Atlas van de Flora van Vlaanderen en het Brussels Gewest. 2006. p. 45-67.

7. Storkey J, Meyer S, Still KS, Leuschner C. The impact of agricultural intensification and land-use change on the European arable flora. Proc Biol Sci. 2011; 279(1732): 1421-1429. http://dx.doi.org/10.1098/rspb.2011.1686

8. Ratyńska H, Boratyński A. Czynna ochrona roślin i zbiorowisk segetalnych i ruderalnych [Active protection of segetal and ruderal plants and vegetation]. Przegl Przyr. 2000; 11(2-3): 43-56.

9. Skrzyczyńska J, Skrajna T. Flora segetalna Wysoczyzny Kaluszynskiej [The segetal flora of the Kałuszyn Upland]. Acta Agrobot. 1999; 52(1-2): 183-202. http://dx. doi.org/10.5586/aa.1999.019

10. Skrzyczyńska J, Skrajna T. Zbiorowiska polne Wysoczyzny Kałuszyńskiej. Cz I. Zespoły zbożowe [Field communities of the Kałuszyn Upland. Part 1. Cereal communities]. Fragm Agron. 2004;4(84):32-44.

11. Skrajna T, Skrzyczyńska J. Chwasty ściernisk Wysoczyzny Kałuszyńskiej [Weeds of stubble fields of the Kałuszyn Upland]. Zesz Nauk Akad Ped Siedlce Ser Rol. 2003; 63: 59-69.

12. Skrajna T, Skrzyczyńska J. Stanowiska wilgociolubnych chwastów polnych na Wysoczyźnie Kałuszyńskiej [Stations of the selected hygrophilous field weeds in the Kałuszyńska Upland]. Fragm Flor Geobot Pol. 2006; 13(2): 293-299.

13. Skrajna T, Skrzyczyńska J. Plant communities and associations of root crops of the Kałuszyńska Upland. Acta Agrobot. 2008; 61(2): 121. http://dx.doi.org/10.5586/ aa.2008.052

14. Woś A. Climatic regions of Poland. Polish Scientific Publishers PWN; 1999. p 183-224.

15. Pawłowski B. Skład i budowa zbiorowisk roślinnych oraz metody ich badania. [In:] Szafer W., Zarzycki K. editor. Szata roślinna Polski I. Warsaw: Polish Scientific Publishers PWN; 1972. p. 237-268.

16. Matuszkiewicz W. Przewodnik do oznaczania zbiorowisk roślinnych Polski. Warsaw: Polish Scientific Publishers PWN; 2001.

17. Korn i a T T. Flora segetalna północno-wschodniej Polski, jej przestrzenne zróżnicowanie i współczesne przemiany
[Segetal flora of north-eastern Poland, its spatial variation and modern changes]. Acta Acad Agric Tech Olst Agric. 1992; 53(supp A): 3-76.

18. Mirek Z, Piękoś-Mirkowa H, Zając A, $\mathrm{Zaj}$ ąc M. Flowering plants and pteridophytes of Poland - a checklist. In: Mirek Z, editor. Biodiversity of Poland. Cracow: W. Szafer Institute of Botany, Polish Academy of Sciences; 2002; 1: 442.

19. Korn aś J. Zespoły synantropijne. [In:] Szafer W, Zarzycki K, editors. Szata roślinna Polski I. Polish Scientific Publishers PWN; 1972; 1: 442-465.

20. P in ke G. Letzte Vorkommen von Caucalidion - Arten im Nordwesten Ungarns. J Plant Prot. 2004; 19: 73-82.

21. Smart SM, Bunce RGH, Marrs R, LeDuc M, Firbank LG, Maskell LC, et al. Large-scale changes in the abundance of common higher plant species across Britain between 1978, 1990 and 1998 as a consequence of human activity: tests of hypothesised changes in trait representation. Biol Conserv. 2005; 124(3): 355-371. http://dx.doi.org/10.1016/j.biocon.2004.12.013

22. Kropáč Z. Segetal vegetation in the Czech Republic: synthesis and syntaxonomical revision. Preslia. 2006; 78: 123-209.

23. Clark CM, Tilman D. Loss of plant species after chronic low-level nitrogen deposition to prairie grasslands. Nature. 2008; 451(7179): 712-715. http://dx.doi.org/10. 1038/nature06503

24. Los o s ova Z, Si m on ova D. Changes during the 20th century in species composition of synanthropic vegetation in Moravia (Czech Republic). Preslia. 2008; 80: 291-305.

25. Towpasz K, Barabasz-Krasny B. Differentiation of segetal vegetation in the Czarnożecko-Strzyżowski Landscape Park (Southeastern Poland). Pam Puł. 2006; 143: 183-193.

26. Węgrzy nek B. Alien plant species as the source of noxious weeds in Poland. In: Pyšek P, Pergl J, editors. Biological Invasion: towards a aynthesis. Neobiota. 8; 2009. p. 111-121.

27. Gołębiowska H, Kaus A. Wpływ zróżnicowanych systemów uprawy na stan zachwaszczenia kukurydzy [Influence of diversified tillage systems on weed infestation in crop maize]. Prog Plant Prot Post W Ochr Roślin. 2009; 49(2): 792-796.

28. Pyšek P, Jarošík V, Kropáč Z, Chytrý M, Wild J, Tichý L. Effects of abiotic factors on species richness and cover in Central European weed communities. Agric Ecosyst Env. 2005; 109(1-2): 1-8. http://dx.doi.org/ 10.1016/j.agee.2005.02.018

29. Głowacka A. Dominant weeds in maize (Zea mays L.) cultivation and their competitiveness under conditions of various methods of weed control. Acta Agrobot. 2011; 64(2): 119. http://dx.doi.org/10.5586/aa.2011.023 


\section{Wpływ sposobu gospodarowania na dynamikę zbiorowisk ze związku Radiolion linoidis (Rias Goday 1961) Pietach 1965 w agrocenozach Wysoczyzny Kałuszyńskiej}

\section{Streszczenie}

W pracy przedstawiono rezultaty badań przeprowadzonych w latach 1994-2010 dotyczących przemian fitocenoz z gatunkami Radiolion linoidis wywołanych wzrostem intensyfikacji procesu produkcji. Materiał badawczy stanowiło 136 zdjęć fitosocjologicznych wykonanych na stałych powierzchniach w uprawach zbóż, okopowych/kukurydzy i na ścierniskach. Zdjęcia pogrupowano na trzy okresy przedstawiające zmiany sposobu produkcji. I-okres (lata 1994-1997) tradycyjny sposób gospodarowania; II - okres (lata 2002-2004) - okres przestawiania produkcji na intensywną i III - okres (lata 2008-2010) - intensywny sposób gospodarowania. W okresie badań, na skutek intensyfikacji uprawy zanikają zbiorowiska z Radiolion linoidis. Notowane w I okresie fitocenozy Spergulario-Illecebretum verticillati na ścierniskach i zbiorowiska z udziałem Illecebrum verticillatum $\mathrm{w}$ uprawach zbóż i okopowych zastępowane są w III okresie przez płaty Echinochloo-Setarietum w zasiewach kukurydzy i na ścierniskach oraz asocjacje Vicietum tetraspermae w zbożach. Wyliczone wartości wskaźników podobieństwa zbiorowisk Sørensena i dynamiki podkreślają głęboki zakres przemian i ubożenia zbiorowisk.

Handling Editor: Elżbieta Weryszko-Chmielewska

This is an Open Access digital version of the article distributed under the terms of the Creative Commons Attribution 3.0 License (creativecommons.org/licenses/by/3.0/), which permits redistribution, commercial and non-commercial, provided that the article is properly cited. 